\title{
A Comparative Study of Physicochemical, Dielectric and Thermal Properties of Pressboard Insulation Impregnated with Natural Ester and Mineral Oil
}

\author{
Ruijin Liao', Jian $\mathrm{Hao}^{1,2}$, George Chen ${ }^{2}$, Zhiqin $\mathrm{Ma}^{1}$ and Lijun Yang ${ }^{1}$ \\ ${ }^{1}$ State Key Laboratory of Power Transmission Equipment \& System Security and New Technology \\ Chongqing University, Shapingba District, Chongqing 400044, China \\ ${ }^{2}$ School of Electronics and Computer Science \\ University of Southampton, Southampton SO17 1BJ, UK
}

\begin{abstract}
Natural ester is considered to be a substitute of mineral oil in the future. To apply natural ester in large transformers safely, natural ester impregnated solid insulation should be proved to have comparable dielectric strength and thermal stability to mineral oil impregnated solid insulation. This paper mainly focuses on a comparative study of physicochemical, ac breakdown strength and thermal stability behavior of BIOTEMP natural ester/pressboard insulation and Karamay 25\# naphthenic mineral oil/pressboard insulation after long term thermal ageing. The physicochemical and dielectric parameters including moisture, acids and the ac breakdown strength of these two oil/pressboard insulation systems at different ageing status were compared. The permittivity and ac breakdown strength of these two oil/pressboard insulation systems at different temperatures were also investigated. And a comparative result of the thermal stability behavior of these two oil/pressboard insulation systems with different ageing status was provided at last. Results show that though natural ester has higher absolute humidity and acidity during the long ageing period, the lower relative humidity of natural ester helps to keep its ac breakdown strength higher than mineral oil. The pressboard aged in natural ester also has higher ac breakdown strength than that aged in mineral oil. The lower relative permittivity ratio of natural ester impregnated paper to natural ester is beneficial to its dielectric strength. Using natural ester in transformer, the resistance to thermal decomposition of the oil/pressboard insulation system could be also effectively improved.
\end{abstract}

Index Terms - Natural ester, mineral oil, pressboard, physicochemical, dielectric strength, thermal stability.

\section{INTRODUCTION}

THE transformer plays an important role in providing a reliable and efficient electricity supply and is one of the most critical equipments in electric power transmission and distribution systems. The majority of high voltage transformers are filled with liquids that work as an electrical insulation as well as a heat transfer medium. The most commonly used liquid in power transformers is mineral oil due to its low cost and good properties. However the performance of mineral oil starts to be limited due to environmental consideration [1-3]. Firstly, conventional transformer oils are usually non-biodegradable; they can contaminate soil and water when a serious spill takes place $[4,5]$. This may disturb the plantation and other organisms. Secondly, the mineral oils were extracted from petroleum, which is going to run out in the future since petroleum is nonrenewable $[5,6]$.

Manuscript received on 18 June 2010, in final form 18 April 2011.
Natural ester insulating fluid offers fire safety, environment, and insulation ageing advantages over mineral oil and are found to be suitable for the use in transformer insulation system $[7,8]$. Previous sealed tube ageing studies show that the thermal ageing rate of virgin paper insulation in natural ester is significantly slower than that in mineral oil [9-11]. At present, two typical commercial products of natural ester are BIOTEMP made by ABB in 1999 and FR3 developed by Cooper in 2000. These two natural esters have currently been used in small power and distribution transformers across the United States, and further improvements are ongoing in the hope that they will be widely applied in large power transformers [3]. Moore [12] presented the requirements and expectations of natural ester fluids for application in power transformers. It has become clear that more research is required to ascertain the long term safe operation of transformers where natural ester is used. 
Oil impregnated pressboard is widely used between transformer windings as oil barriers for breaking up large oil gaps and acting as mechanical support. It normally takes the electrical stress under ac operating voltage and undergoes degradation under a combined stress of thermal (the most important factor), electrical, mechanical and chemical stresses during routine operations. Therefore, the dielectric and thermal stability are the most important properties of dielectric material used in the transformer. However, the long term ac breakdown behavior of the natural ester/pressboard insulation has not been properly studied and the thermal stability of the natural ester/pressboard insulation in the long ageing process also has not been discussed.

In this paper, the physicochemical and dielectric parameters including moisture, acids and the ac breakdown strength of the natural ester/pressboard insulation and mineral oil/pressboard insulation system with different ageing status were compared. The permittivity and ac breakdown strength of these two oil/pressboard insulation systems at different testing temperatures were also investigated. Finally, the thermal stability behaviors of the two oil/pressboard insulation systems at different ageing conditions were analyzed.

\section{EXPERIMENTAL}

Accelerated thermal ageing in sealed systems is recommended in the IEEE loading guide to simulate the real ageing in modern sealed transformers [13]. In this paper, accelerated thermal ageing experiment of natural ester/pressboard insulation and mineral oil/pressboard insulation at $110{ }^{\circ} \mathrm{C}$ was conducted for 120 days. The insulation pressboard used in the experiment was provided by Hunan No.1 Insulation Pressboard Co. Ltd, China. The technical performances of the pressboard satisfy the international standard IEC 641-3-1. These pressboards consist of about $90 \%$ cellulose, $6-7 \%$ hemicellulose, and 3-4\% lignin. The pressboard has a thickness of $0.3 \mathrm{~mm}$ for a single layer. The pressboard was cut into circular samples with a diameter of $42 \mathrm{~mm}$. The insulation oil used in this experiment was Karamay 25\# naphthenic mineral oil, which was degassed and provided by ChuanRun Lubricant Co. Ltd., China. It is an inhibited insulation oil. The mass concentration of 2, 6-di-tertbutyl-4-methylphenol (DBPC) in the oil is $0.3 \%$. This oil has good electrical properties and oxidation stability, which satisfies the ASTM D3487-2000(II). The natural ester used in this research was BIOTEMP natural ester provided by $\mathrm{ABB}$ Chongqing Transformer Co. Ltd.

\subsection{ACCELERATED THERMAL AGEING EXPERIMENT}

The pretreatment of the samples were as follows: firstly, in order to simulate the real ageing conditions in modern sealed transformers, all pressboard samples were put into a vacuum box and dried at $90{ }^{\circ} \mathrm{C}$ for $48 \mathrm{~h}$. Then the temperature of the vacuum box was adjusted to $40^{\circ} \mathrm{C}$. Secondly, the new mineral oil or new natural ester was infused into the vacuum box. The vacuum box was left for $24 \mathrm{~h}$ at $40{ }^{\circ} \mathrm{C}$ before cooled down to room temperature. Thirdly, $63 \mathrm{~g}$ pressboard samples were taken out of the vacuum box each time and put into a glass bottle $(1000 \mathrm{ml})$. Then new mineral oil (or new natural ester) was poured into each bottle at a mass weight ratio of liquid/pressboard equal to 10:1 (each bottle has $630 \mathrm{~g}$ oil and $63 \mathrm{~g}$ pressboard). In order to simulate the effect of copper ion in real transformers, $175 \mathrm{~cm}^{2}$ copper sheet was put into every bottle (according to the adopted proportion by Chongqing ABB Ltd.)[14]. Then every bottle was filled up with nitrogen and sealed $(0.075 \mathrm{MPa}=0.75 \mathrm{~atm})$. These bottles were finally put into the ageing ovens and heated to $110{ }^{\circ} \mathrm{C}$ for the accelerated thermal ageing experiment. The initial moisture content of new mineral oil and new natural ester are $5 \mathrm{mg} / \mathrm{Kg}$ and $36 \mathrm{mg} / \mathrm{Kg}$, respectively. The initial moisture content of new mineral oil impregnated pressboard is $0.37 \%$, and the initial moisture content of natural ester impregnated pressboard is $0.41 \%$. During the ageing process, the physicochemical and dielectric parameters, as well as the thermal stability behavior of oils and oil impregnated pressboards at different sampling intervals were measured. The abbreviation of the samples analyzed is shown in Table 1 .

Table 1. Abbreviation of samples analyzed in the experiment.

\begin{tabular}{c|c}
\hline Sample name & Sample composition \\
\hline NE & natural ester \\
MO & mineral oil \\
PINE & pressboard impregnated in natural ester \\
PIMO & pressboard impregnated in mineral oil \\
\hline
\end{tabular}

\subsection{ANALYTICAL TECHNIQUES 2.2.1 PHYSICOCHEMICAL AND DIELECTRIC PROPERTIES OF OILS AND OIL IMPREGNATED PRESSBOARDS}

The moisture content for various oils was measured at room temperature $\left(27 \pm 0.1^{\circ} \mathrm{C}\right)$ using Karl Fischer Titration method. 3 $\mathrm{ml}$ oil sample was injected into the automatic coulometric Karl Fischer titration unit (METTLER TOLEDO DL32) containing KFR-C04 Karl Fischer Reagent for Coulometric Method Pyridine-free.

Absolute moisture content of oil impregnated pressboards was measured using $0.1 \pm 0.02 \mathrm{~g}$ pressboard sample, carefully handled to avoid moisture exchange with air. Absolute moisture content in pressboard was extracted in METTLER TOLEDO DO308 oven $\left(140{ }^{\circ} \mathrm{C}\right)$ and carried by a dry nitrogen gas flow $(120 \mathrm{ml} / \mathrm{min})$ to the coulometric titration cell. Then the absolute moisture content of pressboard sample was acquired.

\subsubsection{THE ACIDS CONTENT OF OIL AND OIL IMPREGNATED PRESSBOARD}

The acid number of oil was measured according to ASTM D974-2. At present, no standardized method exists for measuring acidity in oil impregnated cellulose paper. L. E. Lundgaard et al studied the method to test the acids content in insulation paper using the extraction/titration method [15]. Firstly, water was used to extract the acids in paper. Secondly, the aqueous phase was titrated according to the method for oil acidity (IEC 60296). In this research, a similar method of extraction/titration was developed. Oil impregnated pressboards with different ageing status were cut into rectangular shape with a dry weight of $2 \pm 0.5 \mathrm{~g}$. In order to 
avoid exposure to atmosphere, the pressboard sample was immediately placed into $100 \mathrm{ml}$ distilled water $\left(27 \pm 0.1{ }^{\circ} \mathrm{C}\right)$ contained in a $250 \mathrm{ml}$ bottle. These bottles including pressboard samples were left for 12 days (stirring one time every 3 days) at $27 \pm 0.1{ }^{\circ} \mathrm{C}$ for a complete acid extraction. Thereafter, $100.3 \mathrm{ml}$ neutralization fluids (50 $\mathrm{ml}$ Absolute Alcohol $+50 \mathrm{ml}$ Ether $+0.3 \mathrm{ml}$ Phenolphthalein) were added into $30 \mathrm{ml}$ water contained in the bottle and the sample was titrated using $\mathrm{KOH}$ in alcoholic solvent $(0.1 \mathrm{~mol} / \mathrm{L})$. Prior to pressboard weighing, the pressboard samples were dried in the vacuum box at $90{ }^{\circ} \mathrm{C}$ for $24 \mathrm{~h}$. All the pressboard samples were weighted to the nearest milligram, and the acidity was calculated in terms of milligram of $\mathrm{KOH}$ per gram dry pressboard.

The ac breakdown voltage of oils was measured using standard cell with electrode space of $2.5 \mathrm{~mm}$ according to IEC 60156. The voltage with a frequency of $50 \mathrm{~Hz}$ was applied at a rise rate $2 \mathrm{kV} / \mathrm{s}$ until breakdown. Tests were performed at room temperature $\left(27 \pm 0.1{ }^{\circ} \mathrm{C}\right)$ and atmosphere pressure. To obtain a homogenous particle distribution, the oil was mixed with a stirrer during the measurement breaks. Five breakdown voltages were obtained for each oil sample and the average value was used for comparison.

The ac breakdown voltage of oil impregnated pressboards was carried out according to the standard IEC 60243-1, which defines the experiment procedures of solid insulation material under ac power frequency voltage. The electrodes consist of two brass cylinders with a diameter of $25 \mathrm{~mm}$, as shown in Figure 1. The electrode edges were rounded to a radius of $3 \mathrm{~mm}$, creating an environment similar to the oil wedge explained previously in $[3,16]$, as shown in Figure 2. The voltage with frequency of $50 \mathrm{~Hz}$ was applied at a rise rate of 2 $\mathrm{kV} / \mathrm{s}$ until breakdown. Five breakdown voltages were obtained for each oil impregnated pressboard sample and the average value was used for comparison.

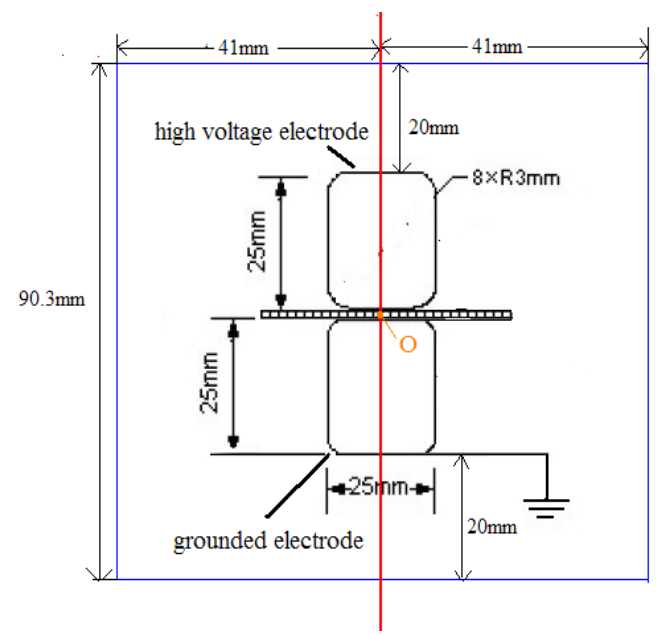

Figure 1. The structure of electrode to measure ac breakdown strength of pressboard

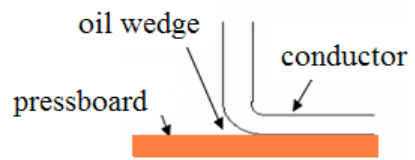

Figure 2. Location of oil wedge in transformer design.

\subsubsection{THE AC BREAKDOWN STRENGTH OF OILS AND OIL IMPREGNATED PRESSBOARDS UNDER DIFFERENT TEMPERATURES}

The ac breakdown strength of oils and oil impregnated pressboards under different temperatures were investigated in an oven where the testing temperature was controlled. The initial moisture contents of new mineral oil and new natural ester are $15 \mathrm{mg} / \mathrm{Kg}$ and $46 \mathrm{mg} / \mathrm{Kg}$, respectively. The initial moisture content of pressboard immersed in natural ester is $0.50 \%$, and the initial moisture content of natural ester impregnated pressboard is $0.49 \%$. The testing temperature range is from 40 to $70{ }^{\circ} \mathrm{C}$. The test method of ac breakdown strength of oils and oil impregnated pressboards at different temperatures are the same as described above (Section 2.2.1).

\subsubsection{THERMAL STABILITY BEHAVIOR OF OILS AND OIL IMPREGNATED PRESSBOARDS}

Thermogravimetry (TG) is a technique in which the mass of a substance is measured as a function of temperature whilst the substance is subjected to a controlled temperature programme [17-21]. It is a useful technique applied to determine the thermal stability of oils and fibers (cellulose) [18-21]. The thermal stability behaviors of natural ester/pressboard insulation system and mineral oil/pressboard insulation system aged for different times were compared firstly in this paper.

Data was collected on Q50 TG Analyzer (TA, America). Each mineral oil sample (15.0-15.4 mg) and natural ester sample (15.0-15.4 mg) were tested from 33 to $250{ }^{\circ} \mathrm{C}$ and 450 ${ }^{\circ} \mathrm{C}$, respectively. The temperature scanning rate was $3^{\circ} \mathrm{C} / \mathrm{min}$ under nitrogen flow $(50 \mathrm{ml} / \mathrm{min})$. Each pressboard sample (5.0-5.2 mg) was tested from 33 to $500{ }^{\circ} \mathrm{C}$ at a temperature scanning rate of $5{ }^{\circ} \mathrm{C} / \mathrm{min}$ under nitrogen flow $(50 \mathrm{ml} / \mathrm{min})$. In this research, the thermal characteristic parameters, including the initial decomposition temperature (IDT), the maximum speed of decomposition (MSD) and the temperature at maximum decomposition speed (TMDS) were focused on.

\section{EXPERIMENTAL RESULTS}

\subsection{MOISTURE CONTENT OF OILS AND OIL IMPREGNATED PRESSBOARDS}

\subsubsection{MOISTURE CONTENT OF OILS}

The absolute moisture content of natural ester and mineral oil during the ageing process is shown in Figure 3. The absolute moisture content of natural ester increases initially and then decreases, lastly increases again slightly when the ageing time increases. While the absolute moisture content of mineral oil has a slight decrease at first, and then increases all the time. Figure 3 indicates that the natural ester has much higher absolute moisture content than mineral oil after experiencing the same ageing length. This is because natural ester has a greater affinity for moisture than does mineral oil [1, 5, 22, 23].

Considering that the saturation moisture content of oil is a function of pressure and especially the temperature, the relative moisture reflects more than just the moisture content $[5,24]$. In this paper, the relative moisture content of natural ester and mineral oil dependence on ageing time was analyzed. The 
relative moisture for oil is the dissolved moisture content of the oil relative to the maximum capacity of moisture that the oil can hold. The relative moisture $W_{\text {rel }}$ at a given temperature $T$ is defined in terms of the actual moisture content in a liquid $W_{\text {abs }}$ versus the saturation limit $W_{L}(T)$ [25], as following:

$$
W_{\text {rel }}=\frac{W_{a b s}}{W_{L}(T)}
$$

The moisture maximum solubility $W_{L}(T)$ at an absolute $T$ can be expressed in the form [26, 27]:

$$
W_{L}(T)=K * e^{-\frac{H}{T}}
$$

The constant $K$ depends on the liquids themselves and is determined experimentally. According to the dependence of the moisture saturation limit of natural ester and mineral oil as a function of absolute temperature previously published in [5], at room temperature, the saturation limits of natural ester and mineral oil are about 3000 and $60 \mathrm{mg} / \mathrm{Kg}$, respectively. According to equation (1), the relative moisture content of natural ester and mineral oil during the ageing process was calculated, as shown in Figure 4. It can be seen that the mineral oil has a higher relative moisture content than natural ester, except for ageing 30 days, where the relative moisture content of mineral oil is almost the same as that of natural ester. Since the moisture has a detrimental effect on the electrical performance of oil $[1,5]$, the lower relative moisture content of natural ester may potentially make the natural ester have better dielectric breakdown strength than mineral oil during the ageing process.

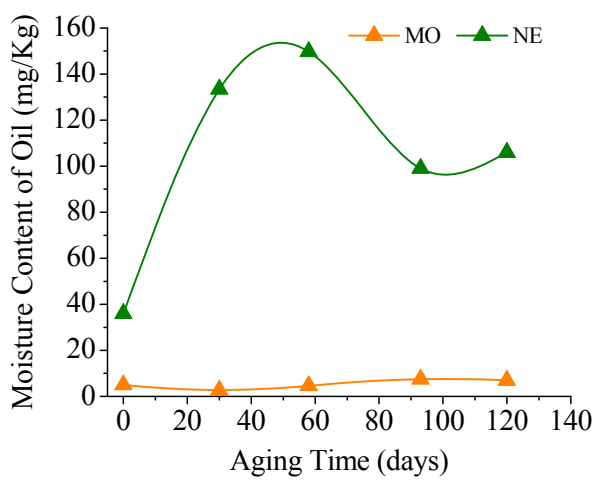

Figure 3. Absolute moisture content of natural ester and mineral oil in the ageing process

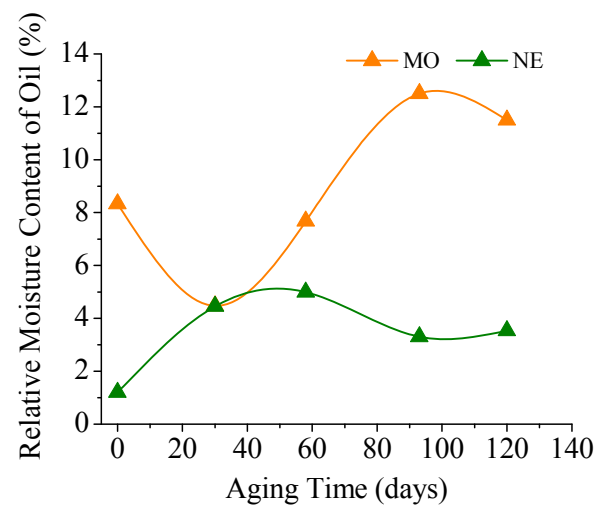

Figure 4. Relative moisture content of natural ester and mineral oil in the ageing process.

\subsubsection{MOISTURE CONTENT OF OIL IMPREGNATED PRESSBOARDS}

The absolute moisture content of oil impregnated pressboards is shown in Figure 5. Moisture moves between the pressboard and dielectric fluid to reach equilibrium in terms of relative saturation [23, 28, 29]. Due to the higher absolute moisture content of new natural ester and the great moisture affinity of pressboard, the pressboard which has very low moisture content will absorb moisture from natural ester at the beginning of ageing in order to keep moisture equilibrium between oil and pressboard. Therefore, the moisture content of the pressboard in natural ester increases in the first stage of ageing. In addition, moisture would be generated because of oil/pressboard insulation deterioration. When sampled at 58 days, the moisture content of natural ester increased to $1.25 \mathrm{wt} \%$, which is the maximum. On the other hand, moisture reacts with the natural ester via hydrolysis. The reaction consumes dissolved moisture in the fluid causing additional moisture to move from the pressboard into the fluid in order to maintain the equilibrium. Hence, the moisture content of pressboards aged in natural ester reduces after ageing 58 days.

In mineral oil/pressboard insulation system, the moisture content of pressboard also increases because of oil/pressboard insulation deterioration generating moisture. However, when the oil and the air inside the bottles being relatively drier than the moisture condition of pressboard, there is always a migration of moisture from the pressboard to the oil and then to the air $[28,29]$. Thus the moisture content of pressboard has a decline. The longer the periods of ageing, the larger is the amount of moisture migrating out from the pressboard [28]. Therefore, the moisture content of the pressboard aged in mineral oil also shows a decrease after ageing 58 days.

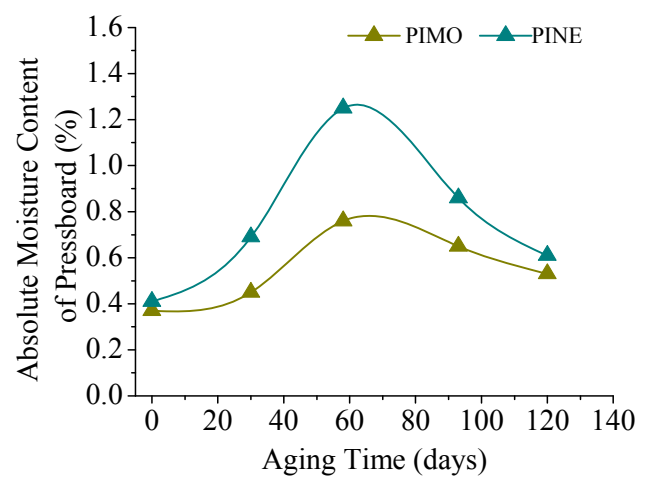

Figure 5. Absolute moisture content of pressboard aged in natural ester and mineral oil.

\subsection{ACIDS CONTENT OF OILS AND OIL IMPREGNATED PRESSBOARDS 3.2.1 ACIDS CONTENT OF OILS}

Figure 6 shows the dependence of acidity of natural ester and mineral oil on ageing time. Under normal condition the acidity of natural ester is higher than mineral oil [1, 22]. This is reflected in Figure 6 at the beginning of the ageing experiment where the acidity of new natural ester is higher than the new mineral oil. Degradation of both natural ester and mineral oil creates acids, so it is not surprising to see that the 


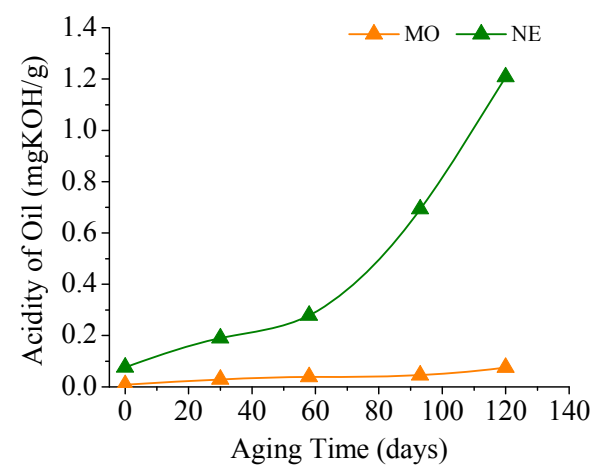

Figure 6. Acidity of natural ester and mineral oil in the ageing process.

acidity of natural ester and mineral oil increases with the ageing time. However, it is worthy to mention that the acidity of natural ester is considerably higher than mineral oil over the whole ageing period. This is because the natural ester degrades in a different manner to mineral oil.

Recognized mechanism of mineral oil is chain reaction of free radical oxidation: including chain off, chain continuity and chain breaking out $[22,30]$. Natural ester consists primarily of triglycerides. Triglycerides are glycerol molecules with three long chain fatty acids attached at the hydroxy groups via ester linkages. Unsaturated double bonds in the fatty acids are active sites for many reactions, including oxidation, lowering the oxidation stability of natural ester. The greater the level of un-saturation, the more double bonds, and the more susceptible to oxidation the natural ester becomes [31]. Natural ester oxidation is initiated by formation of free radicals. Free radicals can easily be formed from the removal of a hydrogen atom from the methylene group next to a double bond. Free radicals rapidly react with oxygen to form a peroxy radical. The peroxy radical can then attack another lipid molecule to remove a hydrogen atom to form a hydroperoxide and another free radical, propagating the oxidation process [31]. In addition, natural ester can hydrolyze in the presence of moisture, which releases fatty acids and glycerol, as presented in equation (3). However, there is no hydrolysis in mineral oil. Therefore, the different chemical reaction in oils results in the natural ester having much higher acidity than mineral oil. On the other hand, due to the differences in the chemical structures of acids formed by natural ester and mineral oil, the acids formed in mineral oil are detrimental $[15,22,35]$, while the acids produced by esters are beneficial [22, 23, 32-34].

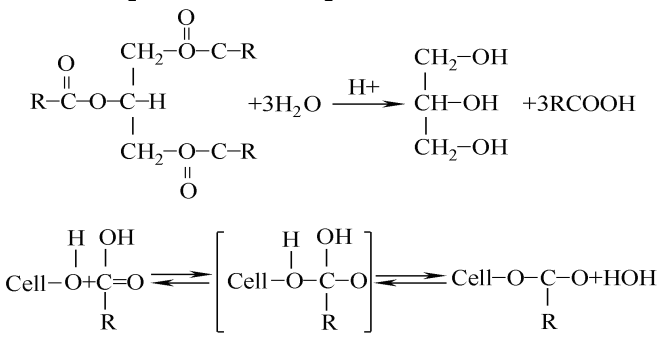

From the components of natural ester and mineral oil, it can be known that the main type of acids in natural ester is high molecular acids, such as oleic acids, while the main type of acids in mineral oil is low molecular acids, such as formic, acetic and levulinic acids [15, 22, 32-35]. The low molecular acids accelerate the ageing of the paper, but the high molecular acids do not influence the paper ageing significantly $[15,22,35]$. The high molecular acids produced by hydrolysis of natural ester can react with the cellulose via transesterification [22, 23, 34, 36], as shown in equation (3). Under accelerated ageing, the reactive $\mathrm{OH}$ (hydroxyl) groups on the cellulose molecule become esterified with fatty acid in natural ester, which restrains the paper ageing $[22,23,34,36]$.

\subsubsection{ACIDS CONTENT OF OIL IMPREGNATED PRESSBOARDS}

Unfortunately, there is no standardized method for measuring acidity in oil impregnated cellulose. In this paper, the acid content in the pressboard aged in natural ester and mineral oil was compared at the first time, as shown in Figure 7. The pressboard aged in natural ester has a much higher acid content than the pressboard aged in mineral oil before 93 days. L. E. Lundgaard et al studied the acids in mineral oil-paper insulation system and proposed that the hydrophilic acids are mostly concentrated in the insulation paper [15, 35]. The lower the molecular weight of acids, the more easily it is absorbed by insulation paper $[15,35]$. It is known, the natural ester has higher acidity than mineral oil and there is hydrolysis reaction which can release acids in natural ester. Compared with the pressboard in mineral oil, the pressboard in natural ester may absorb more acids from the oil. This may be one reason why the pressboard in natural ester has a much higher acid content than the pressboard in mineral oil. Another reason is that there is natural ester in the natural ester impregnated pressboard. The acidity of natural ester is much higher than mineral oil, which can also contribute to the acid content of the pressboard immersed in natural ester. However, the higher acid content in pressboard immersed in natural ester is not bad thanks to the transesterification reaction $[22,23,34,36]$.

Figure 7 shows that the acid content of the pressboard aged in mineral oil is very close to that aged in natural ester after aged for 93 days. It is known that the ageing of pressboard will produce moist soluble carboxylic acids. The severer the deterioration of the pressboard, the larger the quantity of acids it generates $[15,35,37]$. The natural ester can restrain the ageing rate of pressboard effectively $[2,6,9,22,23,34]$. This means that less carboxylic acid will be generated by the pressboard aged in natural ester. Therefore, compared with the

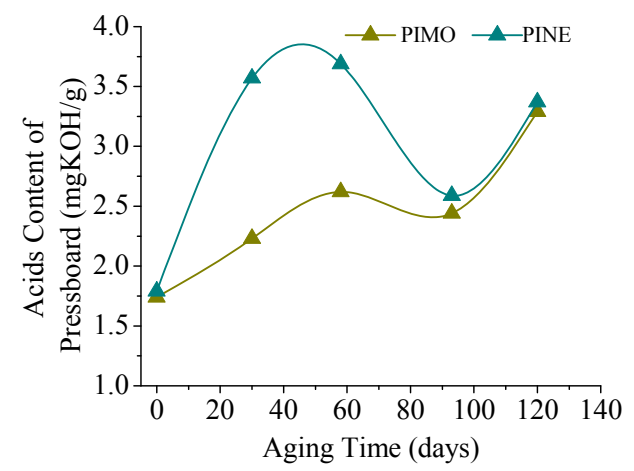

Figure 7. Acids content of pressboard aged in natural ester and mineral oil. 
pressboard aged in natural ester, due to the faster ageing rate of the pressboard in mineral oil, the acid content of the pressboard aged in mineral oil get close to that aged in natural ester after ageing for 93 days. The longer the ageing time, the closer their acid content becomes.

It is noteworthy that there is a decline (ageing for 93 days) in acid content of the pressboard in the ageing period. This is because a majority of carboxylic acids are easily dissolved in a moisture phase [36]. The acids may be transferred from pressboard to oil via moisture migration. However, no data has been reported about the influence of moisture migration on carboxylic acid distribution in oil/paper insulation system. Further investigation in this area is required.

\subsection{DIELECTRIC PROPERTIES OF OILS AND OIL IMPREGNATED PRESSBOARDS \\ 3.3.1 AC BREAKDOWN STRENGTH OF OILS}

The most important and often checked parameter of insulation liquid is the breakdown voltage. The ac breakdown strength results of natural ester and mineral oil during the ageing period are presented in Figure 8. For the natural ester, the high ac breakdown strength value is maintained when sampled at 30, 50, 93 days. However, due to the much higher relative moisture content and acidity of natural ester aged for 120 days (Figure 4 and Figure 6), the natural ester aged for 120 days has much lower ac breakdown strength than the new natural ester.

For the mineral oil, the ac breakdown strength of mineral oil sampling at 50,93 and 120 days are all lower due to its higher relative moisture content and higher oil acidity than the new mineral oil. Additionally, the release of contaminants in the form of sludge generated by oxidation of mineral oil may reduce its breakdown voltage $[5,38]$. It is interesting to notice that the ac breakdown strength of mineral oil sampled at 30 days is much higher than the new mineral oil. The reason for this may be related to the relative lower moisture content of mineral oil aged for 30 days than the new mineral oil (Figure 4 ), even though its acidity has a very slight increase.

Figure 8 shows the comparable result of the average ac breakdown strength of natural ester and mineral oil depending on the ageing time. It is worthy to point out that the ac breakdown strength of natural ester is much higher than mineral oil during the whole ageing process, except for when sampled at 30 days, where the ac breakdown voltage of natural

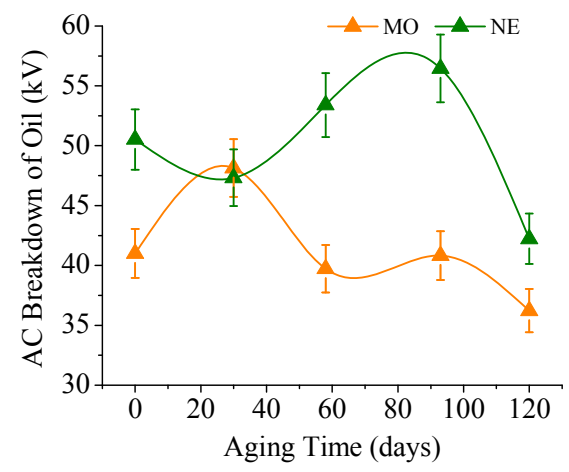

Figure 8. ac breakdown strength of natural ester and mineral oil in the ageing process. ester is similar to the mineral oil aged the same time. The possible reason is that the relative moisture plays an important role in determining electrical performance of oils $[1,5]$. The relative moisture content of natural ester and mineral oil is nearly the same when sampled at 30 days (Figure 4), while the acidity of natural ester is much higher than the mineral oil (Figure 6). The results obtained in Figure 8 clearly show that the natural ester has good ac breakdown behavior in the ageing process, which is optimistic for use in the transformer.

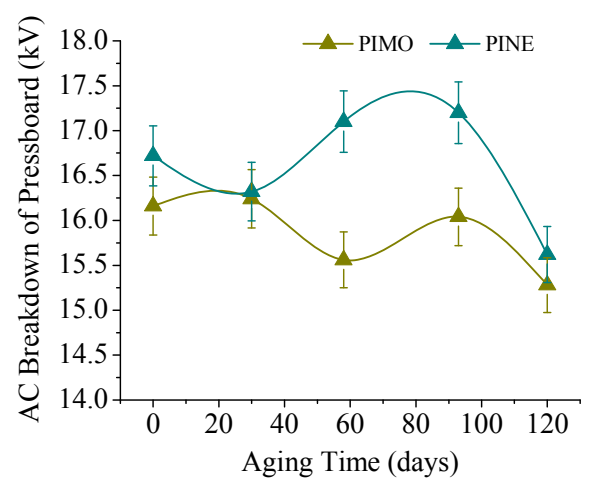

Figure 9. ac breakdown strength of pressboard ( $0.3 \mathrm{~mm}$ thickness) aged in natural ester and mineral oil.

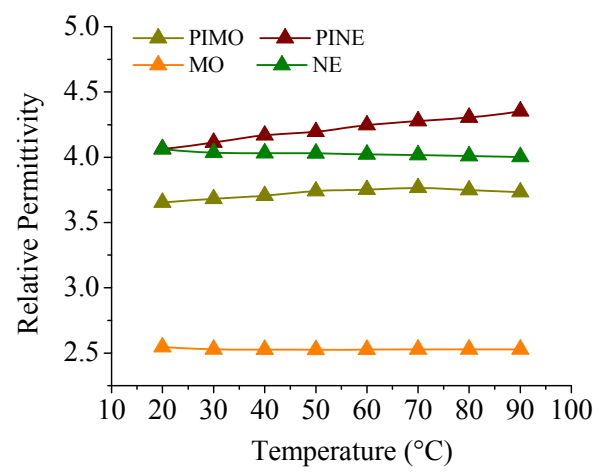

Figure 10. Relative permittivity of oil and oil impregnated pressboard under different temperatures.

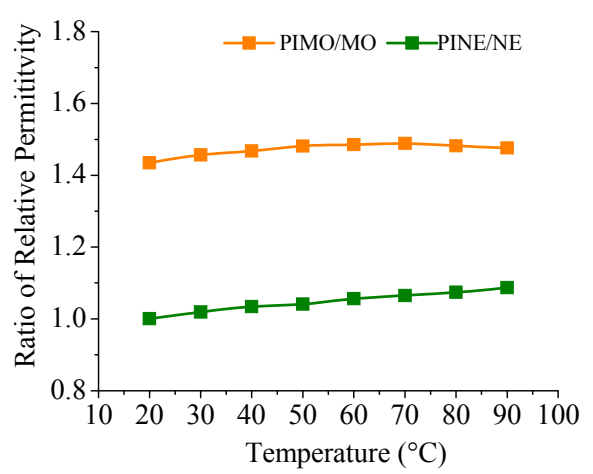

Figure 11. Relative permittivity ratio of oil impregnated pressboard to oil under different temperatures.

\subsubsection{AC BREAKDOWN STRENGTH OF OIL IMPREGNATED PRESSBOARDS}

As shown in Figure 9, the natural ester impregnated pressboard shows a higher ac breakdown strength value than mineral oil impregnated pressboard in the whole ageing process. However, examination of breakdown location has revealed that 
direct breakdown of the pressboard itself rarely happened. This is consistent with results reported before [1]. It is the failure of the weaker component of oil/pressboard interface, that gradually damages the cellulose surface, known as creep discharge [1, 39], and finally causes 'breakdown' of pressboard.

The relative permittivity of natural ester, natural ester impregnated pressboard, mineral oil and mineral oil impregnated pressboard at a wide temperature range of 20-90 ${ }^{\circ} \mathrm{C}$ was measured using Novocontrol Concept 80 Broadband Dielectric Spectroscopy, and the relative permittivity ratio of oil impregnated pressboard to oil was also calculated, as shown in Figures 10 and 11. Natural ester has a higher relative permittivity than mineral oil, which is close to the relative permittivity of oil impregnated pressboard. The permittivity ratio of natural ester impregnated pressboard to natural ester fluid is lower than that of mineral oil impregnated pressboard to mineral oil. Lower permittivity ratio of oil impregnated pressboard to oil is beneficial in oil-pressboard-oil system, since less stress will be distributed in oil duct or oil wedge, which is helpful to prevent the occurrence of the creep discharge [1]. Therefore, less stress would be taken by oil wedge in natural ester/pressboard insulation system, which could prevent creep discharge initiation on natural ester impregnated pressboard. In addition, due to the protecting role of the cellulose pressboard by natural ester, the pressboard in natural ester aged slower than the pressboard in mineral oil, which results in the pressboard in natural ester having better micro-scale properties [40]. So the natural ester impregnated pressboard shows higher ac dielectric strength value than mineral oil impregnated pressboard in the ageing process.

\subsection{THE AC BREAKDOWN STRENGTH OF OILS AND OIL IMPREGNATED PRESSBOARDS UNDER DIFFERENT TEMPERATURE}

\subsubsection{AC BREAKDOWN STRENGTH OF OILS UNDER DIFFERENT TEMPERATURE}

Figure 12 shows the dependence of oil ac breakdown strength on temperature. Because the maximum moisture solubility of insulating liquids increases in an exponential function with temperature [5], the increase in temperature significantly reduces the relative moisture content in the oil. As presented in Figure 13, the relative moisture content of both natural ester and mineral oil reduces with temperature. The reduction of the relative moisture content results in a higher ac breakdown strength $[1,5]$. Thus it is clearly seen that the ac breakdown voltage of both natural ester and mineral oil increases with temperature in the range of $40-70{ }^{\circ} \mathrm{C}$.

It is worthy to note that the ac breakdown strength of natural ester is much higher than mineral oil at these four temperature levels. This is because natural ester has much lower relative moisture content than mineral oil at the same temperature, as presented in Figure 13. Besides, the breakdown of insulating liquid is often initiated by bubbles, the increase of temperature also promotes the formation of peroxide which has a high affinity to hydrogen gas and reduces the formation of bubbles in the ester liquid [5]. Therefore, the ac breakdown voltage of natural ester is much higher than mineral oil in the investigate temperature range of $40-70{ }^{\circ} \mathrm{C}$.

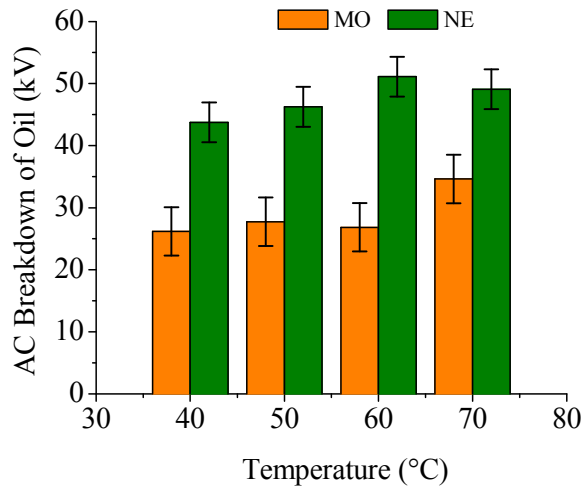

Figure 12. Effect of temperature on ac breakdown strength of natural ester and mineral oil.

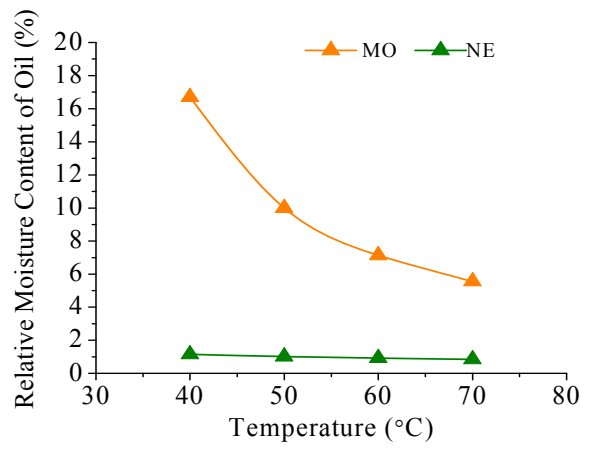

Figure 13. Relative moisture content of natural ester and mineral oil at different temperature.

\subsubsection{THE AC BREAKDOWN STRENGTH OF OIL IMPREGNATED PRESSBOARDS UNDER DIFFERENT TEMPERATURE}

Figure 14 shows the ac breakdown voltage of oil impregnated pressboard dependence on temperature. The natural ester impregnated pressboard also shows higher ac breakdown strength value than mineral oil impregnated pressboard at temperatures of $40,50,60$ and $70{ }^{\circ} \mathrm{C}$.

It can be seen form Figure 10 that the relative permittivity of natural ester and mineral oil decreases slightly with temperature. On the other hand, the relative permittivity of natural ester impregnated pressboard and the relative permittivity ratio of natural ester impregnated pressboard to natural ester increases with temperature. There is the same trend in mineral oil impregnated pressboard from 20 to

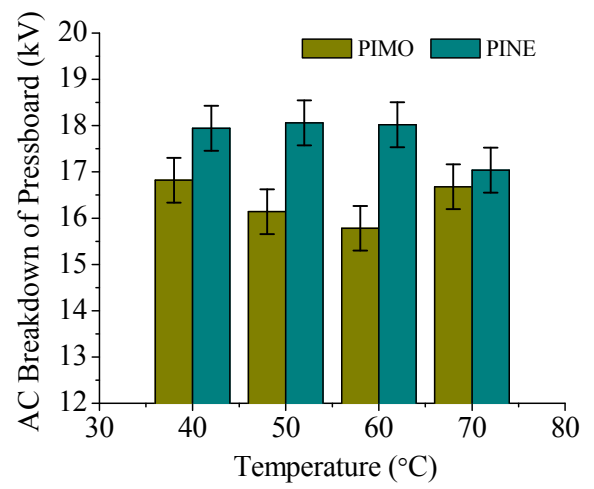

Figure 14. ac breakdown strength of pressboard ( $0.3 \mathrm{~mm}$ thickness) immersed in natural ester and mineral oil under different temperatures. 
$70{ }^{\circ} \mathrm{C}$. However, Figures 10 and 11 show that both the relative permittivity of mineral oil impregnated pressboard and the relative permittivity ratio of mineral oil impregnated pressboard to mineral oil have a slight decline from 70 to 90 ${ }^{\circ} \mathrm{C}$. As described above, the lower permittivity ratio of oil impregnated pressboard to oil is beneficial in oil/pressboard system [1]. Therefore, it can be seen from Figures 11 and 14 that the lower permittivity ratio of natural ester impregnated pressboard to natural ester is good for improving the ac breakdown strength of natural ester/pressboard insulation system.

\subsection{THERMAL STABILITY BEHAVIOR OF OILS AND OIL IMPREGNATED PRESSBOARDS}

\subsubsection{THERMAL STABILITY BEHAVIOR OF OILS}

Figure 15 shows the $\mathrm{TG}$ and the derivative thermogravimetry (DTG) curves of oil samples in natural ester/pressboard and mineral oil/pressboard insulation systems aged for different days. The DTG curve is the first derivative of TG curve. Obviously, decomposition reaction of natural ester and mineral oil mainly has only one step. As presented in Figure 15, the mineral oils start to decompose at the temperature behind $100{ }^{\circ} \mathrm{C}$, while the natural esters start to decompose at the temperature behind $300{ }^{\circ} \mathrm{C}$. Table 2 shows that all natural esters and mineral oils have a slight decrease in their initial decomposition temperature (IDT) with the ageing time, but the initial decomposition temperature of natural esters is about 2.5 times higher than mineral oils at any sampling time.

The difference in thermal behavior of the two oil groups is more visible in their DTG curves. The temperature at maximu-

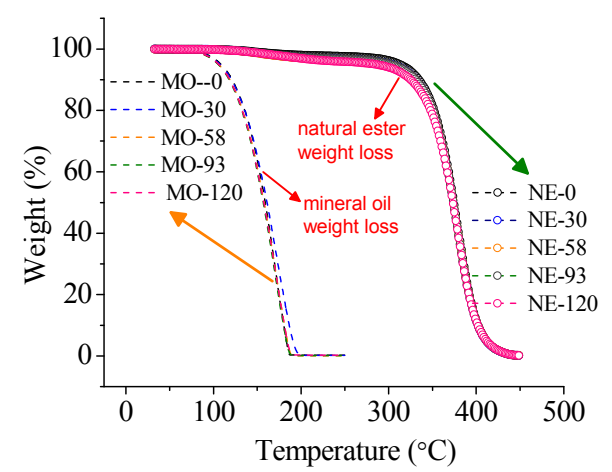

(a) $\mathrm{TG}$

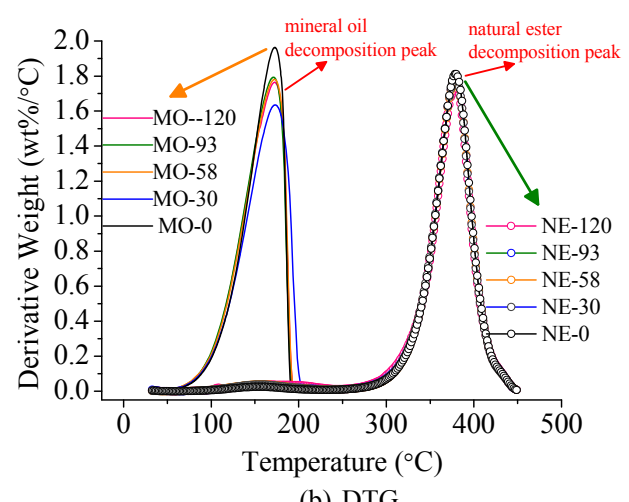

(b) DTG

Figure 15. Thermogravimetry and derivative thermogravimetry of oils. $\mathrm{m}$ decomposition speed (TMDS) of all mineral oils is in the range of $171-174{ }^{\circ} \mathrm{C}$, while the TMDS of all natural esters is in the range of $378-380{ }^{\circ} \mathrm{C}$, which is more than two times higher than mineral oils. The maximum decomposition speed (MDS) of natural esters and mineral oils only has a very slightly difference in the ageing period. From Figure 15 and Table 2, it can be seen that the IDT and TMDS of natural ester are much higher than mineral oil at any sampling time. This indicates that the thermal stability of natural ester is better than mineral oil in the ageing process.

Table 2. Thermogravimetry and derivative thermogravimetry data of oils.

\begin{tabular}{c|c|c|c|c|c|c}
\hline \multirow{2}{*}{$\begin{array}{c}\text { Ageing } \\
\text { time (day) }\end{array}$} & \multicolumn{2}{|c|}{$\begin{array}{c}\text { IDT } \\
\left({ }^{\circ} \mathrm{C}\right)\end{array}$} & \multicolumn{2}{c|}{$\begin{array}{c}\text { TMDS } \\
\left({ }^{\circ} \mathrm{C}\right)\end{array}$} & \multicolumn{2}{c}{$\begin{array}{c}\text { MDS } \\
\left(\% /{ }^{\circ} \mathrm{C}\right)\end{array}$} \\
\cline { 2 - 7 } & $\mathrm{MO}$ & $\mathrm{NE}$ & $\mathrm{MO}$ & $\mathrm{NE}$ & $\mathrm{MO}$ & $\mathrm{NE}$ \\
\hline 0 & 134.23 & 347.41 & 172.57 & 379.39 & 1.963 & 1.813 \\
30 & 132.58 & 346.15 & 173.70 & 378.88 & 1.675 & 1.804 \\
58 & 130.61 & 345.68 & 172.57 & 378.88 & 1.780 & 1.785 \\
93 & 129.69 & 346.75 & 171.06 & 378.88 & 1.794 & 1.786 \\
120 & 129.90 & 345.49 & 172.57 & 379.39 & 1.764 & 1.744 \\
\hline
\end{tabular}

\subsubsection{THERMAL STABILITY BEHAVIOR OF OIL IMPREGNATED PRESSBOARDS}

Cellulose degradation destroys interfibre bonding and causes loss of mechanical strength, leading to tearing and defibrillation [40], so the thermal stability of the pressboard will be changed. The TG and DTG behavior of the pressboards aged in natural ester and mineral oil are shown in Figure 16 and Table 3.

It can be seen from Figure 16 that there are two peaks that can be seen for both natural ester impregnated pressboard and mineral oil impregnated pressboard. This is because there is oil in the oil impregnated pressboard, and the thermal properties of oil and pressboard are different. Compared to the data in Figure 15 and Table 2, it can be known that the initial decomposition temperature of natural esters is about 2.5 times higher than mineral oils, which indicates the mineral oil is easier to decompose, while the natural ester is more difficult to decompose. Therefore, from the TG/DTG results of oil impregnated pressboards shown in Figure 16, there is the mineral oil decomposition peak that occurs before the pressboard decomposition peak, and there is natural ester decomposition peak occurs behind the pressboard decomposition peak. From Figure 16, it can be also concluded that the natural ester has better thermal stability than mineral oil.

As presented in Table 3, it is worth stressing that the initial decomposition temperature (IDT) of the pressboard impregnated in mineral oil nearly reduces with ageing time, while it contrasts to the pressboard impregnated in natural ester. The IDT of the pressboard impregnated in natural ester is around $10{ }^{\circ} \mathrm{C}$ higher than mineral oil impregnated pressboard when sampled at 58, 93 and 120 days. On the other hand, the temperature at the maximum decomposition speed (TMDS) of the pressboard aged in natural ester increases after ageing 30 days, while it contrasts to the pressboard aged in mineral oil. The TMDS of pressboard aged in natural ester is more than $5{ }^{\circ} \mathrm{C}$ higher than that aged in mineral oil when sampled at 58, 93 and 120 days. Besides, the maximum 
decomposition speed (MDS) of the pressboard aged in mineral oil reduces with the pressboard becoming more deterioration. Because of the protective role of natural ester to the cellulose $[2,6,9,22,23,34]$, the pressboard in natural ester has a slower ageing rate than the pressboard in mineral oil. The MDS of pressboard aged in natural ester is slight higher than that in mineral oil in the whole ageing period. Therefore, it can be seen from the thermal parameters shown in Figure 16 and Table 3 that the pressboard aged in natural ester also has good thermal stability than the one aged in mineral oil.

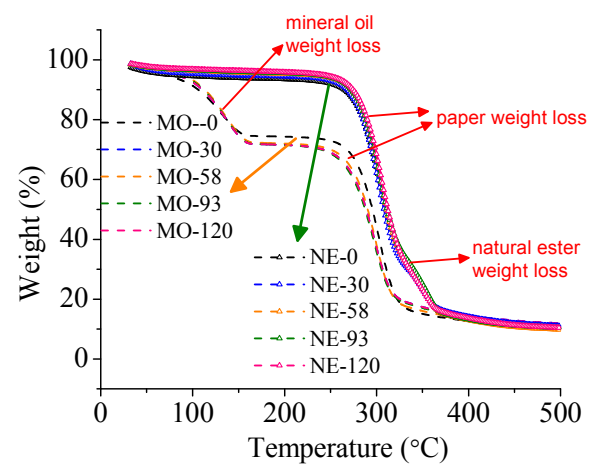

(a) $\mathrm{TG}$

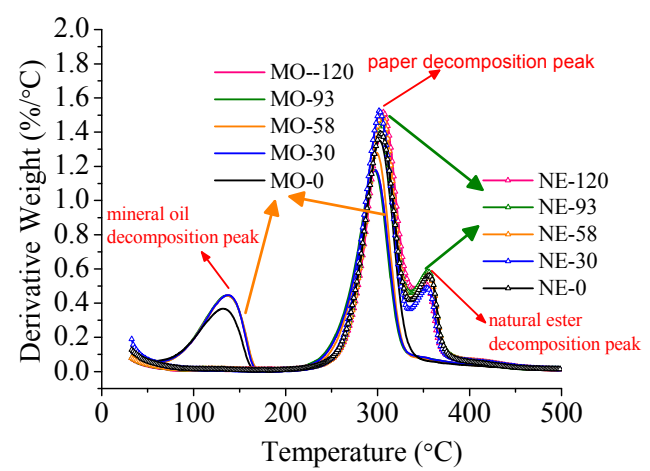

(b) DTG

Figure 16. Thermogravimetry and derivative thermogravimetry of oil impregnated pressboards.

Table 3. Thermogravimetry and derivative thermogravimetry data of oil impregnated pressboards.

\begin{tabular}{c|c|c|c|c|c|c}
\hline \multirow{2}{*}{$\begin{array}{c}\text { Ageing } \\
\text { time (day) }\end{array}$} & \multicolumn{2}{|c|}{$\begin{array}{c}\text { IDT } \\
\left({ }^{\circ} \mathrm{C}\right)\end{array}$} & \multicolumn{2}{c|}{$\begin{array}{c}\text { TMDS } \\
\left({ }^{\circ} \mathrm{C}\right)\end{array}$} & \multicolumn{2}{c}{$\begin{array}{c}\text { MDS } \\
\left(\% /{ }^{\circ} \mathrm{C}\right)\end{array}$} \\
\cline { 2 - 7 } & PIMO & PINE & PIMO & PINE & PIMO & PINE \\
\hline 0 & 277.74 & 279.81 & 302.12 & 303.69 & 1.350 & 1.391 \\
30 & 274.66 & 279.06 & 298.52 & 301.75 & 1.347 & 1.525 \\
58 & 273.82 & 281.65 & 298.81 & 304.40 & 1.279 & 1.498 \\
93 & 269.80 & 280.70 & 296.33 & 303.85 & 1.178 & 1.456 \\
120 & 271.03 & 282.51 & 297.35 & 306.25 & 1.178 & 1.517 \\
\hline
\end{tabular}

\section{DISCUSSIONS}

\subsection{MOISTURE DISTRIBUTION IN OIL/PRESSBOARD INSULATION SYSTEM}

Natural ester molecules are called triglycerides, originating from the chemical linkage of three fatty acids to one glycerol molecule. The structure of a triglyceride ester molecule is illustrated in Figure $17[4,22] . \mathrm{R}_{1}, \mathrm{R}_{2}$, and $\mathrm{R}_{3}$ are fatty acid chains of same or different types. Saturated fatty acids with 8 to 22 carbon atoms are found in oils. Fatty acids with one unsaturated bond have carbon atoms ranging from 10 to 22 . Fatty acids with di-and tri-unsaturation mostly contain 18 carbon atoms. All natural ester molecules are similar in composition. While mineral oil is made of fossil oil and consists of hydrocarbon compounds with various bonds. These molecule structures can be divided into paraffinic, naphthenic, aromatic and olefin bounds [41], as shown in Figure 18. In varying ratios these components are contained in all mineral oils [42].

The chemical structure of natural ester means the natural ester can absorb moisture in chemically bounded and dissolved forms, while in mineral oil, moisture is only slowly dissolved [5, 22, 23]. This means the moisture saturation of natural ester is far higher than that of mineral oil. Therefore, the natural ester has much higher absolute moisture content than mineral oil during the ageing process.

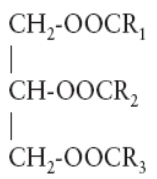

Figure 17. Structure of triglyceride.
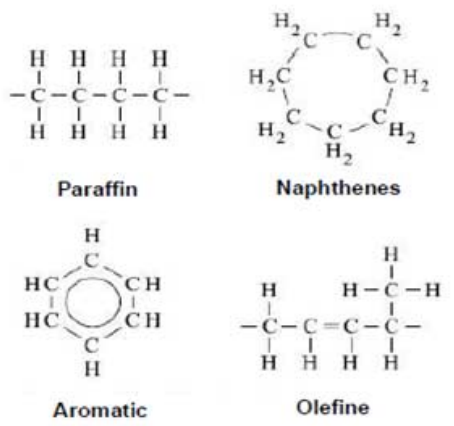

Figure 18. Hydrocarbon compounds in mineral oil.

Moisture is recognized to be the "enemy number one" for transformer insulation after temperature [43]. Moisture is not only one of the most important factors which can accelerate the transformer paper insulation ageing, but also one of the paper ageing products. In order to investigate the moisture distribution behavior of natural ester/pressboard insulation system and mineral oil/pressboard insulation system, the ratio of moisture content in oil and pressboard to the oil/pressboard insulation system were calculated by equation (4) and equation (5) as follows:

$$
\begin{aligned}
& W_{\text {rel-oil }}(t)=\frac{W_{\text {oil }}(t)}{W_{\text {oil }}(t)+W_{\text {paper }}(t)} \\
& W_{\text {rel-paper }}(t)=\frac{W_{\text {paper }}(t)}{W_{\text {oil }}(t)+W_{\text {paper }}(t)}
\end{aligned}
$$

In this ageing experiment, each oil/pressboard insulation sample has $630 \mathrm{~g}$ of oil and $63 \mathrm{~g}$ of pressboard. $\mathrm{W}_{\text {oil }}(t)$ and $\mathrm{W}_{\text {paper }}(t)$ is the total water content in $630 \mathrm{~g}$ oil and $63 \mathrm{~g}$ pressboard at ageing time $t$, respectively, $W_{\text {rel-oil }}(t)$ and $W_{\text {rel- }}$ paper $(t)$ is the ratio of moisture content in oil and in pressboard 
to the total moisture content $W_{\text {oil }}(t)+W_{\text {paper }}(t)$ in the oil/pressboard insulation system at ageing time $t$.

Figure 19 shows the ratio of moisture content in oils to the total moisture content in the oil/pressboard insulation system over the ageing process. It can be clearly seen that the ratio of moisture content in natural ester to the total moisture content in the natural ester/pressboard insulation system is much higher than the ratio of moisture content in mineral oil to the total moisture content in the mineral oil/pressboard insulation system. From Figure 19, it can be deduced that the moisture equilibrium in mineral oil/pressboard insulation is different from that of natural ester/pressboard insulation system over the ageing period. In natural ester/pressboard insulation, much more proportion of moisture tends to stay in the natural ester. While in mineral oil/pressboard insulation system, the moisture tends to remain in the pressboard.

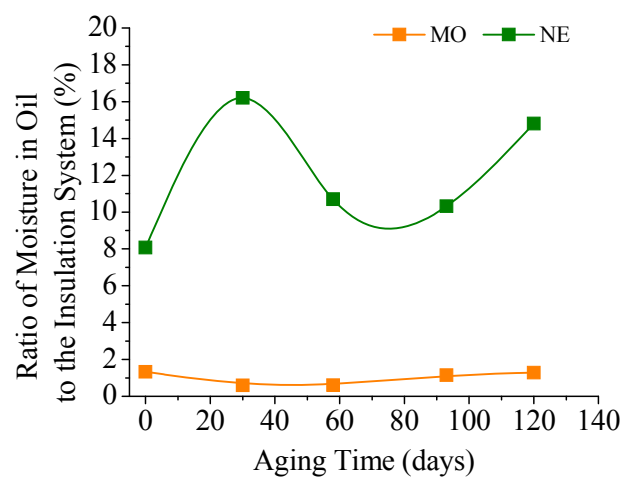

Figure 19. Ratio of moisture content in oils to the total moisture content in the $\mathrm{oil} /$ pressboard insulation system in the ageing process.

\subsection{ELECTRICAL FIELD DISTRIBUTION}

In order to validate why the ac breakdown occurs in the edge of electrode and pressboard immersed in natural ester having higher ac breakdown strength, an electrostatic model using COMSOL was build to simulate the electric field distribution of the testing electrode and oil impregnated pressboard surface. The top electrode was set to $15 \mathrm{kV}$ and the bottom to $0 \mathrm{kV}$. The permittivities were set to 2.5 and 3.7 for mineral oil and mineral oil impregnated pressboard and 3.9 and 4.2 for natural ester and natural ester impregnated pressboard respectively.

The electrical field distribution results for the ac breakdown strength testing structure model of natural ester/pressboard and mineral oil/pressboard were compared. As the electric field distribution results of both top electrode and bottom electrode are the same, only top electrode results are shown in Figure 20 and Figure 21. Figure 20 illustrates that the electrical field at the electrode/pressboard interface has a similar profile in both ac breakdown strength testing structure model of natural ester/pressboard and mineral oil/pressboard. However, there is a big difference in electric field at the point where a small gap locating between the electrode and the pressboard. The peak electric field appears at $9.55 \mathrm{~mm}$ to the center $\mathrm{O}$ of the pressboard (Figure 1). The maximum electric field of natural ester/pressboard is much lower than that of mineral oil/pressboard. Figure 21 is the electric field distribution along the electrode arc surface. It also presents that the natural ester/pressboard has a much lower electric field. Both results above indicate that the natural ester/pressboard system has higher breakdown strength than mineral oil/pressboard system and why the breakdown occurs in the oil wedge, which is the same as the phenomenon observed by the experiment. It is worth to point out that the ac breakdown strength measured here is the characteristic of the whole system, i.e. oil, oil impregnated pressboard and electrode arrangement. So the behavior may be different from those purely concentrated on breakdown characteristics of mineral oil and natural ester [44] under different electrode gaps.

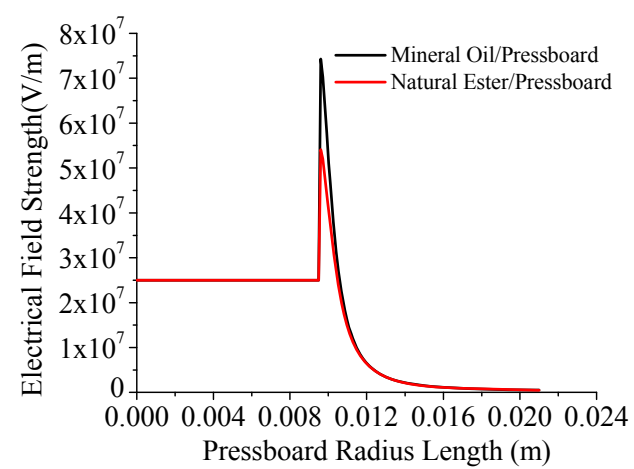

Figure 20. Electric field distribution along the oil impregnated pressboard. Surface.

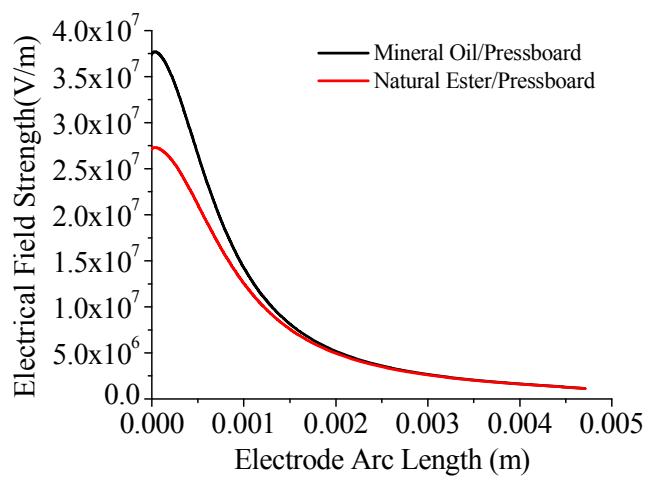

Figure 21. Electric field distribution along the electrode arc surface.

\section{CONCLUSIONS}

A comparative study of the physicochemical, dielectric and the thermal stability behavior of natural ester/pressboard insulation and mineral oil/pressboard insulation over the ageing process show that using natural ester in transformer, the insulation system has not only a more superior ac dielectric property, but also the superior thermal stability of the insulation system. These results may add credence that natural ester can be used in transformer safely. The conclusions could be draw from this research as follows:

The natural ester has a higher absolute moisture content than mineral oil in the ageing process, while the mineral oil has a much higher relative moisture content than natural ester, except for ageing 30 days, where the relative moisture content of mineral oil is similar to that of natural ester. 
Compared with mineral oil, the absolute moisture content and acids content of the pressboard aged in natural ester are much higher than that aged in mineral oil before ageing for 93 days, since then the absolute moisture content and acids content of pressboard aged in two oils are close to each other. The detailed mechanisms are not clear and further research on the influence of migration of moisture on acid transport is required.

The ac breakdown strength of natural ester is much higher than mineral oil during the whole ageing process, except for when sampled at 30 days, where the ac breakdown voltage of natural ester is only comparable with the mineral oil aged the same time. The natural ester impregnated pressboard shows higher ac breakdown strength value than mineral oil impregnated pressboard over the whole ageing period.

The lower permittivity ratio of natural ester/impregnated pressboard to natural ester is beneficial to the ac breakdown strength of natural ester/pressboard insulation system. The ac breakdown strength of natural ester is much higher than mineral oil at temperatures of $40,50,60$ and $70{ }^{\circ} \mathrm{C}$, and the natural ester impregnated pressboard also shows higher ac breakdown strength value than mineral oil impregnated pressboard in these temperatures.

The thermal stability of natural ester/ pressboard insulation system is better than mineral oil/ pressboard insulation system in the ageing process. The IDT and TMDS of natural ester and natural ester impregnated pressboard are higher than mineral oil and mineral oil impregnated pressboard at any sampling time.

The moisture equilibrium in mineral oil-pressboard insulation is different from that of natural ester-pressboard insulation system in the ageing period. In the natural ester/pressboard insulation, moisture tends to remain in the natural ester, while in the mineral oil/pressboard insulation system moisture tends to remain in the pressboard.

\section{ACKNOWLEDGMENT}

All the authors thank Chinese National Basic Research 973 Program of China (2009CB724505-1) and the Scientific Research Foundation of SKL of Power Transmission and System Security (2007DA10512708103) for the financial support provided. One of the authors (Jian Hao) wishes to thank the Chinese Scholarship Council Funding for Joint Training Ph.D. Student.

\section{REFERENCES}

[1] D. Martin, I. Khan, J. Dai and Z. D. Wang, "An overview of the suitability of vegetable oil dielectrics for use in large power transformers", $\mathrm{TJ} / \mathrm{H}_{2} \mathrm{~b}$ Euro TechCon Conf., Chester, UK, pp. 1-20, 2006.

[2] L. Yang, R. Liao, C. Sun and H. Sun, "Study on the influence of natural ester on thermal ageing characteristics of oil-paper in power transformer", Int'l. Conf. High Voltage Eng. Application, Chongqing, China, pp. 437-440, 2008.

[3] D. Martin, Z. D. Wang, P. Dyer, A. W. Darwin and I. R. James, "A comparative study of the dielectric strength of ester impregnated cellulose for use in large power transformers", IEEE Int'l. Conf. Solid Dielectr., Winchester, UK, pp. 294-297, 2007.

[4] T. V. Oommen, "Vegetable oils for liquid-filled transformers", IEEE Electr. Insul. Mag., Vol. 18, No. 1, pp. 6-11. 2002.
[5] Suwarno, I. S. Darma, "Dielectric properties of mixtures between mineral oil and natural ester from palm oil", World Scientific and Engineering Academy and Society (WSEAS) Trans. on Power Systems, Vol. 3, No. 2, pp. 37-46, 2008.

[6] T. V. Oommen, C. C. Claiborne and J. T. Mullen, "Biodegradable electrical insulation fluids", IEEE Electr. Insul. Conf., and Electr. Manufacturing \& Coil Winding Conf., Rosemont, IL, USA, pp. 465-468, 1997.

[7] C. P. McShane, "Vegetable-oil-based dielectric coolants", IEEE Industry Applications Mag., Vol. 8, No. 2, pp. 34-41, 2002.

[8] S. W. Liang, R. J. Liao and L. J. Yang, "Study on the accelerated thermal ageing of nature ester-paper insulation and mineral oil-paper insulation", Chinese Soc. Electr. Eng. (CSEE), Vol. 28, No. 25, pp. 2024. 2008 (in Chinese).

[9] C. P. McShane, J. L. Corkran, K. J. Rapp and and J. Luksich, “Ageing of paper insulation retro-filled with natural ester dielectric fluid", IEEE Conf. Electr. Insul. Dielectr. Phenomena (CEIDP), Albuquerque, USA, pp. 124-127, 2003.

[10] Y. Bertrand and L. C. Hoang, "Vegetal oils as substitute for mineral oils", 7th Int'l. Conf. Properties and Applications of Dielectric Materials (ICPADM), Nagoya, Japan, Vol. 2, pp. 491-494. 2003.

[11] C. Perrier, A. Beroual and J. L. Bessede, "Improvement of power transformers by using mixtures of mineral oil with synthetic esters", IEEE Int'l. Conf. Dielectr. Liquids, Coimbra, Portugal, pp. 389-392, 2005.

[12] H. R. Moore, "Requirements and Expectations of Natural Ester Fluids for Application in Power Transformers", 2005/2006 IEEE PES Transformers Conf. Exhibition Transmission and Distribution, pp. 1-2, 2006.

[13] IEEE Guide for loading mineral-oil-immersed transformers. IEEE Standard 1995; C57: 91-1995.

[14] R. J. Liao, C. Tang, L. J. Yang, F. Yun and C. X. Sun, "Influence of the copper ion on ageing rate of oil-paper insulation in a power transformer", The Institution of Engineering and Technology (IET) Electr. Power Appl., Vol. 3, pp. 407-412, 2009.

[15] L. E. Lundgaard, W. Hansen and S. Ingebrigtsen, "Ageing of mineral oil impregnated cellulose by acid catalysis", IEEE Trans. Dielectr. Electr. Insul., Vol. 15, No. 2, pp. 540-546, 2008.

[16] H. Tsukioka, E. Ohe, Y. Kamata, M. Maejima, M. Nozaki, K. Hyodo, "Development of low dielectric constant pressboard", The Twenty-First Symposium on Electrical Insulating Materials, France, pp. 31-34, 1988.

[17] R. C. Mackenzie, "Nomenclature in thermal analysis: Part IV", J. Thermal Anal. Vol. 13, pp. 387-392, 1978.

[18] V. Mentlik, P. Prosr and R. Polansky, "Ageing of petroleum and synthetic based insulation oils from the view of structural analyses", IEEE Int'l. Conf. Dielectr.Liquids, Poitiers, France, pp. 1-4, 2008.

[19] S. Sathivel, W. Prinyawiwatkul, I. I. Negulescu, J. M. King and B.F.A. Basnayake, "Thermal degradation of FA and catfish and menhaden oils at different refining steps", J. American Oil Chem. Soc., Vol. 80, pp. 1131-1134, 2003.

[20] X.Y. Liu and W.D. Yu, "Evaluating the thermal stability of high performance fibers by TGA", J. Appl. Polymer Sci., Vol. 99, pp. 937$944,2006$.

[21] P. Cerruti, V. Ambrogi, A. Postiglione, J. Rychly, Lyda Matisova Rychla', and Cosimo Carfagna, "Morphological and thermal properties of Cellulose-montmorillonite nanocomposites", Biomacromolecules, Vol. 9, No. 11, pp. 3004-3013, 2008.

[22] R. Liao, S. Liang, C. Sun, L. Yang and H. Sun, "A comparative study of thermal ageing of transformer insulation paper impregnated in natural ester and in mineral oil', European Trans. Electr. Power, Vol. 20, No. 4, pp. 518-533, 2010.

[23] K. J. Rapp, C. P. McShane and J. Luksich, "Interaction mechanisms of natural ester dielectric fluid and Kraft paper", IEEE Int'l. Conf. Dielectr. Liquids, Portugal, pp. 393-396, 2005.

[24] Y. Du, M. Zahn, B. C. Lesieutre, A. V. Mamishev, S. R. Lindgren, "Moisture equilibrium in transformer paper-oil systems," IEEE Electr. Insul. Mag., Vol. 15, No. 1, pp. 11-20, 1999.

[25] I. Fofana, V. Wasserberg, H. Borsi and E. Gockenbach, "Challenge for a mixed insulating liquid for using in high voltage transformers. Part 1: Investigation of mixed liquids", IEEE Electr. Insul. Mag., Vol. 18, No. 3, pp. 18-31, 2002. 
[26] IEC 60296 or DIN 57370, "Specifications for new insulating oils for transformers and switchgear".

[27] M. Beyer, W. Boeck, K. Möller and W. Zaengel, "Hochspannungstechnik-Theoretische und praktische Grundlagen, Springer Verlag, 1986.

[28] T. K. Saha and P. Purkait, "Understanding the impacts of moisture and thermal ageing on transformer's insulation by dielectric response and molecular weight measurements", IEEE Trans. Dielectr. Electr. Insul., Vol. 15, pp. 568-582, 2008.

[29] T. V. Oommen, "Moisture Equilibrium Charts for Transformer Insulation Drying Practice", IEEE Trans. Power App. Syst., Vol. 103, pp. 3063-3067, 1984.

[30] R. Sanghi, "Chemistry Behind the Life of a Transformer", Resonance, pp. 17-23. 2003.

[31] N. J. Fox and G. W. Stachowiak, "Vegetable oil-based lubricants-A review of oxidation”, Tribology Int'l., Vol. 40, pp. 1035-1046, 2007.

[32] L. Lewand, "Laboratory testing of natural ester dielectric liquids", InterNational Electrical Testing Association (NETA) World, pp. 52-57, 2004.

[33] V. Sokolov and D. Hanson, "Impact of oil properties and characteristics on transformer reliability", Fifth AVO New Zealand International Technical Conf., Methven, New Zealand, pp. 1-14, 2006.

[34] C. P. McShane, K. J. Rapp, J. L. Corkran, G. A. Gauger and J. Luksich, "Ageing of paper insulation in natural ester dielectric fluid", IEEE/PES Transmission \& Distribution Conf. Exposition, Atlanta GA, Vol. 2, pp. 675-679, 2001.

[35] L. E. Lundgaard, W. Hansen, S. Ingebrigtsen, D.Linhjell and M. Dahlund, "Ageing of Kraft paper by acid catalyzed hydrolysis", 2005 IEEE International Conference on Dielectric Liquids (ICDL), Coimbra, Portugal, pp. 381-384, 2005.

[36] G. Chauvelon, L. Saulnier, A. Buleon, J. F. Thibault, C. Gourson, R. Benhaddou, R. Granet and P. Krausz "Acidic activation of cellulose and its esterification by long-chain fatty acid", J. Appl. Polymer Sci., Vol. 74, pp. 1933-1940, 1999.

[37] S. Ingebrigtsen, M. Dahlund, W. Hansen, D. Linhjell and L. E. Lundgaard, "Solubility of carboxylic acids in paper (Kraft)-oil insulation system", IEEE Conf. Electr. Insul. Dielectr. Phenomena (CEIDP), Trondheim, Norway, pp. 253-257, 2004.

[38] C. C. Claiborne, E. J. Walsh and T. V. Oommen, "An agricultural based biodegradable dielectric fluid”, IEEE. Conf. Electr. Insul., New Orleans, USA, pp. 876-881, 1999.

[39] N. K. Bedoui, A. Beroual and F. Chappuis, "Creeping discharge on solid/liquid insulatinginterface under AC and DC voltages", IEEE Conf. Electr. Insul. Dielectr. Phenomena, Vol. 2, pp. 15-18, 2000.

[40] R. Liao, C. Tang, L. Yang and S. Grzybowski, "Thermal ageing microscale analysis of power transformer pressboard", IEEE Trans. Dielectr. Electr. Insul., Vol. 15, No. 5, pp. 1281-1287, 2008.

[41] A. Küchler, Hochspannungstechnik 2, Springer Verlag Berlin, Heidelberg 2005.

[42] G. J. Pukel, R. Schwarz, F. Schatzl, F. Baumann and A. Gerstl, "Environmental friendly insulationg liquids-A challenge for power trnasformers", Cigré 2009 6th Southern Africa Regional Conf., Cape Town, South Africa, No. P510, 2009.

[43] I. Fofana, H. Borsi and E. Gockenbach, "Challenge for a mixed insulating liquid for using in high voltage transformers. Part2: Dielectric behaviour of the mixed liquids impregnated paper insulation", IEEE Electr. Insul. Mag., Vol. 18, No. 4, pp. 5-16, 2002.

[44] C. T. Duy, O. Lesaint, A. Denat, and N. Bonifaci, "Streamer propagation and breakdown in natural ester at high voltage", IEEE Trans. Dielectr. Electr. Insul., Vol. 16, No. 6, pp. 1582-1594, 2009.

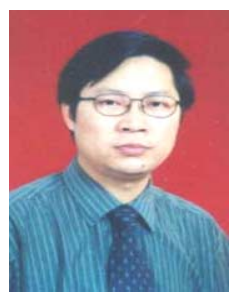

Ruijin Liao was born in Sichuan, China in 1963. He received the M.S. and Ph.D. degrees in electrical engineering from Xi'an Jiaotong University, China and Chongqing University, China, respectively. Since 1999 he is a professor of Electrical Engineering College at Chongqing University, China. His research activities lie in the field of on-line monitoring of insulation condition and fault diagnosis for high voltage apparatus, as well as ageing mechanism and diagnosis for power transformer. $\mathrm{He}$ is author/ coauthor of one book and over 90 journal and international conferences.

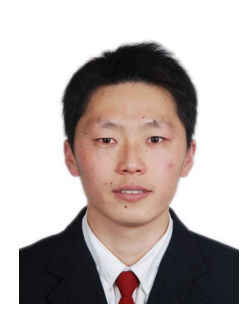

Jian Hao was born in Hebei, China in 1984. He received the B. Eng. degree and B. Econ. degrees (2007) from the College of Electrical Engineering and College of Economics and Business Administration, Chongqing University, China. Now, he is a Ph.D. candidate in the College of Electrical Engineering, Chongqing University, China. From 2010 to 2011, as a Ph.D. student. He works on the dielectric response characteristics and space charge research of oil-paper insulation in University of Southampton, UK. His research activities are mainly in the field of ageing mechanism, dielectric response characteristics and online monitoring of oil-paper insulation system for high voltage apparatus.

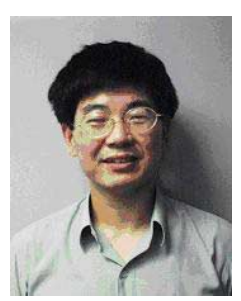

George Chen was born in China in 1961. He received the B.Eng. (1983) and M.Sc. (1986) degrees in electrical engineering from Xi'an Jiaotong University, China. After he obtained the Ph.D. degree (1990) from the University of Strathclyde, UK, on the work of permanent changes in electrical properties of irradiated low-density polyethylene. He joined the University of Southampton as postdoctoral research fellow and became a senior research fellow subsequently. In 1997 he was appointed as a research lecturer and promoted to a Reader in 2002. Over the years, he has developed a wide range of interests in high voltage engineering and electrical properties of materials and published over 200 papers.

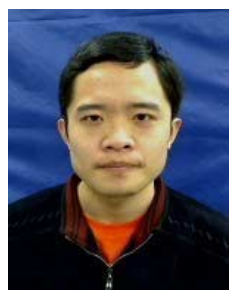

Zhiqin Ma was born in Henan, China in 1986. He received the B.Eng. degree (2009) in electrical engineering from Chongqing University, China. His major research interests include online detection of insulation condition of electrical devices, and insulation fault diagnosis for high voltage equipment.

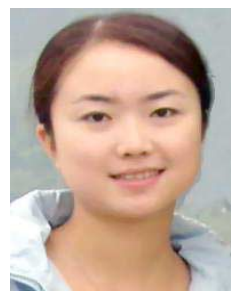

Lijun Yang was born in Sichuan, China in 1980. She received her M.S. and Ph.D. degrees in electrical engineering from Chongqing University, China in 2004 and 2009. Her major research interests include online detection of insulation condition of electrical devices, partial discharges, and insulation fault diagnosis for high voltage equipment. 